\title{
A DIDÁTICA DA LÍNGUA DE SINAIS FRANCESA: NASCIMENTO OU RECONHECIMENTO DE UMA DISCIPLINA DE PLENO DIREITO? ${ }^{1}$
}

\author{
LA DIDACTIQUE DE LA LANGUE DES SIGNES \\ FRANÇAISE: NAISSANCE OU RECONNAISSANCE \\ D'UNE DISCIPLINE À PART ENTIÈRE?
}

\author{
Véronique Geffroy \\ Université Paris Lumières, Paris, France \\ Élise Leroy \\ Université Toulouse, Toulouse, France
}

Resumo: Por muito tempo excluídos do sistema educacional para a criança surda, os estudos sobre a Língua de Sinais Francesa (LSF) e sobre os surdos que sinalizam se fizeram presentes no campo universitário no início dos anos 1980, na França. Uma vez que essa língua atípica remete antes à universalidade da comunicação e à relação com o mundo do que tão somente à surdez, as questôes colocadas por seu ensino e as especificidades do público concernido se revelam finalmente mais transversais do que se imaginava. A partir de então, as pesquisas sobre a LSF podiam se originar de diversos campos das ciências humanas. Um breve histórico da integração à universidade dessa língua, que foi por tanto tempo desconsiderada, nos permitirá analisar a adequação de seu lugar nas ciências da linguagem e a postura do pesquisador nesse domínio. Certamente o "despertar surdo" do final dos anos 1970 alimentou-se da mobilização das associaçôes recentemente criadas pelo meio surdo, mas é a história das pesquisas sobre a LSF que nos conduzirá aqui a sondar o lugar que ela poderia ocupar. Ao entrar no quadro das ciências da linguagem, uma língua visual e tida como menor como a LSF congregou novas forças. Em decorrência disso, uma eventual didática da LSF pode existir fora do campo da deficiência. A questão que daí decorre é, então, a da pertinência de criar uma disciplina que lhe seja dedicada. Assim sendo, as pesquisas sobre os surdos e a língua viso-gestual que lhes é intrinsecamente ligada oferecem igualmente uma contribuição original mais dinâmica fora do campo da surdez. Finalmente, a emergência de novas ideias e a definição de conceitos inéditos decorrentes dos trabalhos sobre os surdos na sociedade e, em particular, sobre o uso que fazem de uma língua gestual presidem a uma efervescência epistemológica que possui algo de delicado

\footnotetext{
${ }^{1}$ Texto originalmente publicado em: GEFFROY, Véronique; LEROY Élise. La didactique de la langue des signes française : Naissance ou reconnaissance d'une discipline à part entière ? Travaux interdisciplinaires sur la parole et le langage (TIPA), Aix-en-Provence, n. 34, p. 1-28, 2018. Disponível em: http://journals.openedition.org/tipa/2653. Acesso em: 18 dez. 2019. Tradução de Décio Rocha
} 
e, ao mesmo tempo, jubilatório.

Palavras-chave: bilinguismo, língua de sinais, LSF, surdez, deficiência auditiva, educação, epistemologia, estudos surdos.

Résumé: Longtemps évincée du système éducatif pour l'enfant sourd, les études sur la langue des signes française (LSF) et les sourds signeurs se sont inscrites dans le champ universitaire au début des années 1980, en France. Puisque cette langue atypique renvoie davantage à l'universalité de la communication et au rapport au monde qu'à la seule surdité, les questions posées par son enseignement et les spécificités du public concerné sont finalement plus transversales qu'il n'y parait. Dès lors, les recherches sur la LSF pouvaient relever de plusieurs champs des sciences humaines. Un bref historique de l'intégration à l'université de cette langue longtemps déconsidérée nous permettra d'analyser l'adéquation de sa place dans les sciences du langage et la posture du chercheur dans ce domaine. Certes, le "réveil sourd " de la fin des années 1970 s'est nourri de la mobilisation des associations nouvellement créées par le milieu sourd, mais c'est l'histoire des recherches sur la LSF qui nous conduira ici à sonder la place qu'elle pourrait avoir. En entrant dans le panel des sciences du langage, une langue visuelle et minorée comme la LSF a puisé de nouvelles forces. De ce fait, une éventuelle didactique de la LSF peut exister en dehors du champ du handicap. La question qui en découle est alors la pertinence de créer une discipline qui lui soit dédiée. Cela dit, les recherches sur les sourds et la langue visuogestuelle qui leur est intrinsèquement liée apportent également une contribution originale mais dynamique hors du champ de la surdité. Finalement, l'émergence d'idées nouvelles et la définition de concepts inédits issues des travaux sur les sourds dans la société, et en particulier sur leur usage d'une langue gestuelle, président à un bouillonnement épistémologique ayant quelque chose de délicat et de jubilatoire à la fois.

Mots-clés: bilinguisme, langue des signes, LSF, surdité, déficience auditive, éducation, épistémologie, deaf studies.

\section{Preâmbulo}

A surdez perturba a relação entre seres a priori comunicantes. Todos aqueles que ouvem são tão deficientes para comunicar com os surdos quanto os surdos o são em sua comunicaçáo com os ouvintes. Um dos efeitos de tal situação é que se produz uma deficiência compartilhada ${ }^{2}$, invertendose mesmo às vezes os lugares: uma pessoa surda recebe de algum modo um treinamento intensivo para remediar os malentendidos, adotando estratégias que facilitam a intercompreensão, enquanto os ouvintes são, antes, desprovidos de tal treinamento ${ }^{3}$. Kahne (2013) compreendeu bem

${ }^{2}$ Mottez, um dos primeiros pesquisadores a ter acompanhado o "despertar surdo", mostrou muito bem a importância de ver a surdez como uma relaçáo que causa impacto sobre todos os protagonistas em suas trocas.

${ }^{3}$ Essas estratégias são, aliás, apresentadas, em cursos de LSF consagrados à cultura surda, como hábitos de vida dos surdos. Algumas foram explicitadas pelos trabalhos em psicologia cognitiva 
essa situação ao trabalhar em atividades de formação específicas para os gestores da Airbus, uma vez que, para o autor, a realidade é que os surdos que sinalizam comunicam mais rapidamente e com mais precisão do que os ouvintes.

Por outro lado, em toda situação de aprendizagem, é imperativo "não aceitar que não se compreenda, não aceitar que alguém não se faça compreender" (BARUK, 1992, in TERRAIL, 2009, p. 276). Tal posição deve mesmo ser colocada como uma "exigência ética" essencial do ofício de aluno e, também, da deontologia do ensino (BARUK, 1992, in TERRAIL, 2009 , p. 276). Essa exigência recebe uma atenção muito particular em uma situação de ensino em que o professor deve se fazer compreender por um ou vários alunos surdos que devem, eles também, ser compreendidos pelo professor $^{4}$, tendo-lhes sido recusado por muito tempo o uso de uma língua rica, precoce e confortável na educação dos surdos.

A história da Língua de Sinais Francesa (LSF) e das particularidades socioculturais surdas ${ }^{5}$ foi marcada por insistentes polêmicas. $\mathrm{O}$ fato mais marcante foi a recusa generalizada, explicitada em 1880, de utilizar uma língua viso-gestual na instrução dos alunos surdos. Logo alguns anos mais tarde, com as leis de Jules Ferry, a França, instaurando a única língua nacional como língua de ensino, adotará uma lei para escolarizar todas as crianças da República, exceto os surdos, cujo destino devia ser decidido mais tarde. A partir de então, para as crianças surdas, "o ensino da fala e a formação profissional precede(ra)m a inculcação dos conhecimentos" (BUTON, 2009, p. 311), o que significou para essas crianças um desvio da finalidade da escola durante muito tempo. A deriva provocada então prende-se ao fato de que a tecnicidade exigida pela produçáo vocal e leitura labial vai "monopolizar" toda a atenção que poderia ser dispensada aos conteúdos escolares, assim como às interaçôes entre professor e aluno(s) surdo(s).

O destino táo particular da LSF pôde se encontrar com o de outras possíveis línguas de ensino, como as línguas regionais ou minoritárias, tendo em vista que o uso de qualquer outra língua que não fosse o francês como

de Courtin sobre a atenção conjunta, entre outros.

4Para Mottez (in BENVENUTO, 2006), “a surdez é uma relação”, e para Grosjean (2000), é preciso defender "o direito da criança surda crescer como bilíngue".

${ }^{5}$ Nossa discussão aqui não pretende tratar do particularismo cultural surdo (vivência partilhada sem se conhecer, sentimento de pertencimento a um grupo de pares, hábitos de vida, estratégias de comunicação, adaptação à vida em sociedade, etc.) Porém, como para qualquer outra língua, cada vez que se trata de "LSF", de "língua dos surdos" ou de "língua gestual", a cultura a ela associada deverá ser levada em consideraçáo. 
língua de escolarização tinha se tornado impensável para o ensino até o final do século XX. Mesmo se, no início do século XXI, o reconhecimento da LSF como uma das línguas da França ${ }^{6}$ constitui um avanço importante, nem por isso os estudos realizados no campo da surdez se voltaram realmente para o estudo da política linguística adotada em relação a todas as línguas da República.

No que diz respeito às questóes de educação, os métodos e, consequentemente, a formação dos professores se centraram por mais de um século na vocalizaçáo pelo fato de que "o método oral exige teoricamente dos professores que eles tenham noçóes relativas aos mecanismos fisiológicos da articulaçáo" (BUTON, 2009, p. 311). As pesquisas que dizem respeito aos surdos se voltam prioritariamente para a aquisição de um nível de competência em francês satisfatório para a escola, mas cabe perguntar se são os mesmos "objetos" que se analisam segundo se façam pesquisas sobre a deficiência auditiva e as açóes corretivas ou sobre os surdos e a LSF.

Ainda que um professor pudesse se apoiar numa comunicação sem entraves junto a seus alunos surdos com uma língua viso-gestual de qualidade, tendo em vista que a modalidade das trocas não era afetada pela deficiência auditiva, a utilização da LSF em ambiente escolar tinha sobrevivido até a virada do século XXI apenas para os alunos com deficiência associada, isto é, alunos em relação aos quais não havia muitas expectativas. Será preciso esperar meados dos anos 1970, com o "despertar surdo", para que a questão da língua de ensino na educação das crianças surdas seja retomada.

Muito rapidamente, uma associação como "2 Línguas Para uma Educaçáo" (2LPE), criada no final de 1979 e onde se encontravam profissionais surdos, profissionais ouvintes e pais de crianças surdas, tinha

6A França subscreveu a carta europeia das línguas minoritárias em 1999, mas ainda não a ratificou, apesar da promessa de campanhas feitas por François Hollande, em 2012. O relatório do comitê consultivo para a promoçáo das línguas regionais e da pluralidade linguística interna estabeleceu em 2013 uma lista das línguas suscetíveis de dizerem respeito à carta, e a LSF fazia parte das línguas "não territoriais". O texto foi rejeitado pelo Senado em outubro de 2015.

${ }^{7} \mathrm{O}$ período comumente designado por "despertar surdo", primeiramente pelos próprios surdos, mas em especial desde os trabalhos de Kerbourch, em 2006, acerca do movimento daí decorrente, começa em meados dos anos 1970. Certos autores tomam como ponto de partida o congresso da FMS em Paris, em 1971, mas é mais comum tomar como referência a viagem de Mottez e Deck a Washington, em 1975, ou o retorno de uma outra viagem de 1978, da qual participavam profissionais e familiares. A definição de uma baliza final é mais imprecisa: o "despertar surdo" chegou ao fim com a criação das primeiras turmas bilíngues em 1984, ou com o reconhecimento da LSF em 2005? Talvez ainda não esteja concluído. A questão não está resolvida. 
denunciado o comprovado fracasso escolar das crianças surdas e combatido a escolha exclusiva do francês oral em lugar da LSF. Aproximadamente no mesmo momento, a perspectiva de um novo oralismo ressurgia com métodos ou instrumentos novos ${ }^{8}$, de modo que o lugar da língua visogestual no ensino para os surdos levantou questóes inéditas em um campo que se tornou mais polêmico ainda.

Seja como for, o ponto de vista inverso àquele que tinha se imposto há um século se fez ouvir: uma autêntica relação pedagógica pode se estabelecer entre indivíduos "que falam de um outro modo" buscando compreender e se fazer compreender por meio de uma língua gestual.

Nas páginas seguintes, propomos-nos refletir sobre onde situar o estudo da LSF e os aspectos didáticos que a acompanham, começando por examinar de que modo essa língua se tornou objeto de estudo na universidade, apesar das resistências.

\section{A chegada da língua de sinais à universidade}

\section{Algumas referências históricas}

Nos anos 1960-1970, linguistas e sociólogos americanos como Stokoe e Markowicz (linguistas ouvintes entre outros no laboratório da Universidade Gallaudet, Washington, Distrito de Colúmbia, Estados Unidos) tinham começado a estudar a língua viso-gestual dos surdos - o que constituía uma novidade - aproximadamente no momento em que a sociologia se tornava "interacionista" e que o socioconstrutivismo entrava no cenário escolar, lembrando na educação dos surdos o ensino mútuo que tinha existido há muito tempo com a "linguagem mímica".

Seguindo esse mesmo caminho, um pesquisador francês vai se interessar pelos surdos em meados dos anos 1970: Mottez, sociólogo formado por Touraine no Centro dos Movimentos Sociais, logo seguido por Cuxac (linguista), na França, ou Grosjean (psicolinguista), na Suíça.

Como os gestos tinham sido rejeitados por mais de um século, eles eram vistos como um código limitado que não podia ser considerado como língua. Por isso, as questôes sobre a educação dos surdos se voltavam para o aperfeiçoamento do francês oral, em particular em sua modalidade articulatória, o que produziu uma confusão latente que Mottez formulava

${ }^{8}$ Trata-se aqui do método verbo-tonal e, também, de uma codificação complementar à leitura labial (LPC), ou ainda das tecnologias desenvolvidas no reconhecimento vocal. 
em 1979 com as seguintes palavras: "sendo a surdez uma patologia, a língua dos surdos também o seria” (in BENVENUTO, 2006, p. 252).

O dinamismo de associaçóes como, dentre outras, IVT ${ }^{9}, \operatorname{ALSF}^{10}$, SERAC ${ }^{11}$ para Paris, e 2LPE em nível nacional, assim como a abertura de alguns profissionais nas instituiçóes especializadas encarregadas da educação dos surdos, que trabalharam em suas salas de aula inicialmente com "a porta fechada”, produziram, porém, alguns efeitos (MATO, 2017). Profissionais ouvintes tentavam analisar suas práticas ou faziam pesquisa-ação. Entre eles, tornavam-se cada vez mais numerosos os que trabalhavam com surdos sinalizadores no cotidiano, e alguns não hesitavam a se lançar em pesquisas de caráter científico. Nos anos 1980-1990, ao lado dos pesquisadores, os atores de campo vinham à universidade para avaliar suas práticas e para assentá-las em princípios teóricos diferentes. Isso explica por que o público das primeiras manifestaçóes de caráter científico era majoritariamente constituído por assalariados, tendo por vezes também o estatuto de estudante ou de alguém que frequentava cursos sem estar formalmente inscrito.

Porém, os surdos, que precisavam tudo reconstruir depois de um século de interdição de sua língua, não podiam pretender ter acesso ao nível universitário e se preocupavam, portanto, menos ainda em engendrar um novo campo de pesquisa. Sem dúvida nenhum avanço teria sido possível sem que aqueles poucos universitários que ali trabalhavam oferecessem um apoio inesperado aos surdos sinalizadores e a um público mais vasto interessado pelas mesmas temáticas (MATO, 2017). Como é o caso de todos os pesquisadores implicados em um cenário polêmico, sem necessariamente serem militantes engajados, seus trabalhos contribuíram para formalizar o que existia por ali e permitiram, por efeito cumulativo, a estruturaçáo de saberes até então empíricos.

Ainda que Mottez, que atuou como engrenagem fundamental das pesquisas francesas sobre os surdos e sua língua, tenha apoiado o "despertar surdo", são trabalhos em linguística que serão as primeiras alavancas para uma outra educação dos surdos: o bilinguismo. "As defesas de tese de Cuxac e de Bouvet em 1980 e 1981 sobressaem por terem sido as primeiras na França a acolher intérpretes em língua de sinais e um público constituído em grande parte por pessoas surdas" (DALLE-NAZEBI, 2006, p. 420).

International Visual Theater.

${ }^{10}$ Academia da Língua de Sinais Francesa.

${ }^{11}$ Sourds Entendants Recherche Action Communication [em português, Surdos Ouvintes Pesquisa Ação Comunicação]. 
É preciso ainda citar o trabalho de Grosjean, psicolinguista e professor honorário da Universidade de Neuchâtel, que teve uma repercussão importante na França.

De início, a língua viso-gestual dos surdos será introduzida nas universidades francesas como um tema bastante "exótico" e, depois, cada vez mais cobiçado. Esse objeto de estudos tão singular tanto para a pesquisa, na qual ele estimula a reflexão epistemológica, quanto para as aplicações práticas que daí decorrem para o ensino, se implantará inicialmente no campo da linguística, como uma língua de pleno direito vinte anos antes de seu reconhecimento oficial ${ }^{12}$, e permitirá finalmente introduzir a questão dos surdos em vários outros campos universitários.

Como as ciências sociais em geral se interessam pelas atividades humanas, pelas condiçôes (naturais e culturais) e pelos resultados dessas atividades, os instrumentos dos historiadores ${ }^{13}$, sociólogos ${ }^{14}$, psicólogos ${ }^{15}$, filósofos ${ }^{16}$, antropólogos e etnólogos ${ }^{17}$ contribuirão verdadeiramente para dirigir um olhar atento e novo para os utilizadores da LSF, durante aproximadamente trinta anos. Dito isto, a situação complexa e inédita dos surdos e de sua língua na França foi difícil de descrever. Um tal objeto de estudo não se deixa facilmente apreender, abordado ora por um olhar semelhante ao que se dirige às minorias, ora pela ótica da deficiência.

Desse modo, os anos 1980 catalisaram o início da entrada da língua

\footnotetext{
${ }^{12} \mathrm{O}$ reconhecimento oficial da LSF como "língua de pleno direito" é recente, datando da lei de fevereiro de 2005 para a igualdade dos direitos e das oportunidades, a participação e a cidadania das pessoas deficientes (art. L312-9-1, lei n²005-102, de 11 de fevereiro de 2005). É um senador, Nicolas About, que propóe uma emenda adotada por unanimidade pelo Senado em $1^{\circ}$ de março de 2004, antes de figurar na lei de 11 de fevereiro de 2005. Incitando jovens a aprender, ele desejava acima de tudo evitar que os surdos e os portadores de problemas de audição fossem "excluídos" do resto do mundo. Ele esperava mesmo suscitar vocaçóes de intérprete, muito pouco numerosos (uma centena, à época), e tinha por objetivo atingir aproximadamente 1600 pessoas ensinando nessa língua.

${ }^{13} \mathrm{Em}$ primeiro lugar, Cuxac, cuja tese versava sobre a história da língua de sinais na França, enquanto a tese de Estado de 1996 versava sobre a iconicidade de um ponto de vista linguístico, e Karacostas, cuja tese em medicina versava sobre a Instituição nacional dos surdos-mudos de Paris, de 1790 a 1800 . Em seguida, Encrevé e Cantin.

${ }^{14} \mathrm{Na}$ França, principalmente Mottez. Depois, Kerbourc'h e, mais recentemente, Mato.

${ }^{15}$ Meynard e Courtin (pesquisador no CNRS em Ciências cognitivas do desenvolvimento, falecido em 2010).

16Benvenuto.

${ }^{17}$ Humphries e Padden, nos Estados Unidos. Bacci, por exemplo, e depois Delaporte e Schetrit, na França.
} 
de sinais na universidade na França. É somente no curso da segunda metade dos anos 1990 que serão abertos os primeiros cargos universitários de mestre de conferência para docentes-pesquisadores ouvintes trabalhando com a língua de sinais: em sociolinguística, em Rouen, em 1994; em linguística, em Paris, 1998, etc. (GARCIA; BURGAT, 2016). Será um período no curso do qual pesquisadores e atores do campo, surdos ou ouvintes (associaçóes, professores, educadores, comediantes...) unirão suas forças, movidos pelos mesmos objetivos: difundir e fazer reconhecer essa língua batizada a partir de então $L_{S F}{ }^{18}$ como uma das línguas da França ${ }^{19}$, oferecer uma educação bilíngue (LSF- francês escrito) às crianças surdas e proporcionar aos surdos adultos acesso aos saberes e à informação.

\section{Em busca de uma ancoragem teórica adequada}

A surdez atualiza facetas mal conhecidas da capacidade humana de construir sentido ${ }^{20}$. Pode-se dizer que os primeiros trabalhos universitários sobre a LSF criaram, em torno da comunidade surda, um campo de estudos transdisciplinares, o que é bastante raro para ser sinalizado. Alguns linguistas, sociolinguistas, psicolinguistas, para citar apenas as disciplinas que são mais frequentemente mobilizadas, acompanharam juntos uma reflexão de fundo sobre a utilização dessa língua no ensino. Engajaram-se a título individual e foram marginalizados em um primeiro momento, mas contribuíram, cada um com sua parcela, para que a LSF fosse reconhecida como "língua de pleno direito" na França. Pouco numerosos num primeiro momento, um estudo retomava os demais, permitindo uma inteligibilidade comum das questóes assim abordadas. Cada pesquisador, com a metodologia e o rigor de sua disciplina (Mottez, na sociologia; Cuxac, na linguística; Courtin, na psicologia cognitiva), abriu espaços de encontro entre surdos e ouvintes (DALLE-NAZEBI, 2006).

\footnotetext{
${ }^{18}$ Essa denominação, proposta em 1988 por Mottez (in BENVENUTO, 2006, p. 269) para a língua de sinais em uso junto aos surdos, é construída com base no mesmo princípio que a sigla americana ASL para American Sign Language.

${ }^{19}$ Isso se alcançará somente em 2005, e esse reconhecimento oficial foi reafirmado pela DGLFLF, que depende do Ministério da Cultura, em dezembro de 2012 (texto arquivado e disponível para consulta: http://www.dglfff.culture.gouv.fr/lgfrance/lgfrance presentation. htm).

${ }^{20}$ Ver os trabalhos de Cuxac (2007 e 2010), Courtin e Limousin (2010), Leroy (2010), Kahne (2013) e outros.
} 


\section{Ciências da Linguagem}

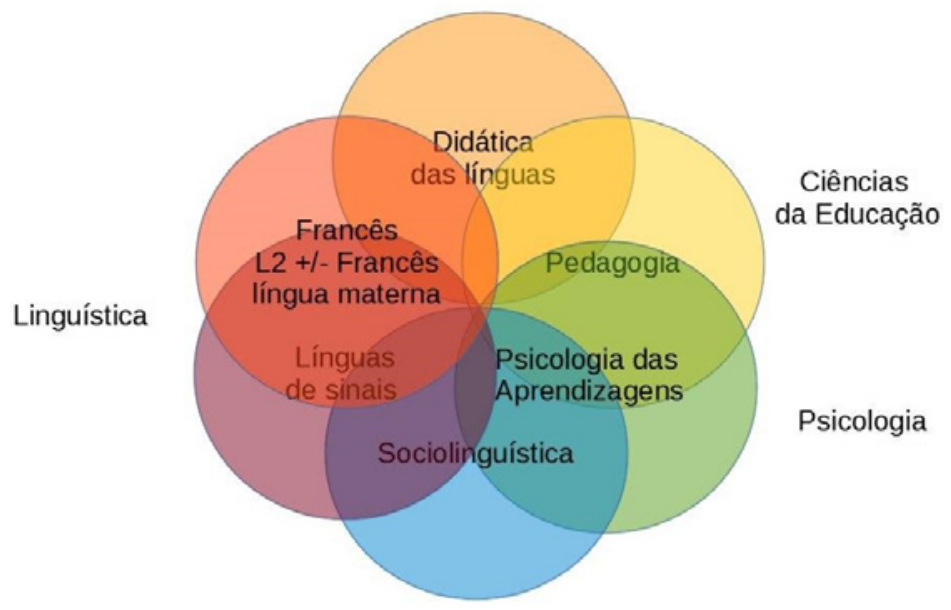

Sociologia

Fig. 1: Campo de estudos transdiciplinares

Agora que as pesquisas sobre os surdos são cada vez mais numerosas e os campos disciplinares mais diversos, elas procuram não mais se fechar em uma única disciplina; evoluem frequentemente tentando cruzar várias abordagens e poderiam então ser interdisciplinares. Assim, muitos pesquisadores visam a uma certa pluridisciplinaridade.

Por outro lado, a questáo da representatividade mereceria ser aqui tratada rapidamente. Os dados numéricos confundem quase sempre todas as deficiências, o que pode ser um indicador da evolução do olhar a eles dirigido pela sociedade dos "sãos", mas não diz muito sobre o destino das pessoas em situaçáo de deficiência, e menos ainda sobre o destino das crianças com necessidades educativas particulares.

Quando as enquetes quantitativas não apresentam seus dados misturando todas as deficiências, elas superpóem frequentemente cegos e surdos na rubrica "deficiências sensoriais", a fim de responder a critérios de representatividade e de não raciocinar sobre quantidades consideradas como 
negligenciáveis ${ }^{21}$. Seja como for, quando uma categoria "deficiência auditiva" existe, ela carece de granularidade: nada distingue quem é e quem não é utilizador da língua de sinais, nem quem segue sua escolaridade em inclusão, em estabelecimento médico-social ou em turmas específicas em LSF, o que constitui um elemento de discriminação fundamental, permitindo avaliar tanto a aquisição das competências de tipo escolar, quanto a socialização ou a autoestima, para cada um dos dispositivos sem a priori. Além disso, a utilização precoce de um primeiro modo de comunicação em uma criança surda, seguido de um outro em determinadas etapas de seu percurso, opacifica a medida das vantagens da oralização ou da LSF na educação ${ }^{22}$.

As diferentes competências e as necessidades dos profissionais que já atuam no campo nunca foram verdadeiramente repertoriadas, e os programas de formação evoluíram "por alteraçóes sucessivas", quando uma "renovação integral" seria necessária. Ainda resta explorar um vasto território que é da competência das ciências da linguagem, das ciências da educação e da engenharia de formação.

\section{Conhecer o campo sem comprometer a neutralidade do pesquisador}

Os pioneiros da pesquisa sobre o particularismo surdo na França propuseram uma argumentaçáo de alto nível, mantendo a inteligência e a modéstia de deixar os surdos encontrar seu lugar e avançar por si mesmos. É o que mostram as pesquisas de Kerbourc'h (2006), de Feldman (2001) e de Mato (2017) descrevendo o papel central de certos universitários no acompanhamento do "despertar surdo". Os ouvintes implicados no meio surdo nem de longe tiveram essa postura.

Poderia parecer que há conflito de interesse, de algum modo, quando se fala do papel dos universitários, sendo nós mesmos autores e em posição de pesquisadores. Porém, não são nossos próprios trabalhos que valorizamos aqui, mas os trabalhos anteriores de outros pesquisadores:

\footnotetext{
${ }^{21}$ Observar os quantitativos recentes da DEPP (2017) ou ainda os dados que vêm sendo reunidos por Ebersold (2013).

${ }^{22}$ Quando registramos os depoimentos dos surdos (crianças ou adultos que foram antigos alunos), como Mottez havia feito já em 1979 para La sourdité dans la vie de tous les jours [A surdez na vida cotidiana], é difícil captar o que, para além do sofrimento pessoal, permitiu seu sucesso escolar ou profissional. No entanto, se não se buscam os meios para acessar a fala dos próprios surdos, é totalmente absurdo concluir algo a respeito do que permite ou não tal ou qual modo de comunicação.
} 
nossos "precursores", como diziam os surdos sinalizadores a respeito das grandes figuras da comunidade surda de antigamente... Não falar deles no momento em que a questão de uma eventual didática específica nos leva a observar o lugar da LSF e de seus utilizadores no seio da universidade, ao contrário, faria muita falta.

Quando alguém se lança em uma pesquisa sobre os surdos, de forma mais acentuada do que em outros campos do trabalho educativo ou social, está sempre presente a questão do grau de implicação ou de seu engajamento militante. Seria realmente preciso ocupar uma posição exterior à surdez para não ser capturado na emoção, sob o risco de se tornar um observador posicionado em um mirante? Mas o que significa então "exterior"? Os discursos dos médicos, dos psicólogos ou dos especialistas da patologia da linguagem que trabalham com a surdez seriam mais legítimos e, portanto, mais bem aceitos aos olhos das instâncias de supervisão? Ou, ao contrário, seria necessário estar envolvido com a deficiência - um envolvimento pessoal ou de alguém próximo - para estar autorizado a tratar de tal ou qual aspecto da questáo? Mas, no caso, o que significa "envolvido"? De que modo levar em consideração os avanços do movimento Nothing about us without us, cujas origens se situam nos anos 1990, referentes a suas escolhas linguísticas feitas para os surdos na França?

\section{O lugar das pesquisas sobre os surdos na universidade}

As línguas gestuais são línguas naturais produzidas pela atividade humana. Podem-se encontrar nelas semelhanças com outras línguas, ou estabelecer elos entre a minoria surda e outras minorias, ou entre as dificuldades de aprendizagem de determinadas crianças surdas e outras situaçóes de aprendizagem.

Com uma língua acessível, a instrução e as capacidades de raciocínio, tanto na língua nacional quanto em todos os outros campos disciplinares abordados na escolaridade, apresentam impressionantes semelhanças com o ensino de qualquer outra criança. Isso não é certamente pouco significativo, fazendo do ensino das crianças surdas um desafio educativo como outro qualquer, pouco importando então a capacidade de vocalização distinta da criança e a leitura labial de seu professor ou de seus colegas de classe.

Tendo em vista que a utilização da LSF para ensinar a uma criança surda melhora sua compreensão de todas as disciplinas escolares, quer 
o aluno seja capaz de oralizar ou náo, incluindo o estudo do francês e a aprendizagem da leitura ${ }^{23}$, a questão da língua de escolarização das crianças surdas se situa potencialmente nas ciências da educação.

\section{Estar em conformidade com as condiçóes de uso da língua sinalizada}

No contexto pedagógico, a natureza do ato educativo, a relação entre aprendiz(es) e professor(es) e as práticas desenvolvidas pelo profissional devem ser reconsideradas sob uma nova perspectiva no caso de um público de crianças surdas. Com efeito, considerando as línguas que permitem atividades cognitivas e metacognitivas e que podem ser igualmente utilizadas de modo intangível nas trocas verbais ligadas ao trabalho social, assim como em conferências, em campanhas eleitorais, em um telejornal ou em debates da Assembleia Nacional, quais delas deveriam se contentar com um lugar entre as línguas veiculares?

Colocar a questão da língua escolhida e fazer eventualmente a escolha de um procedimento outro que não seja o utilizado com o francês oral exclusivamente conduz, ao mesmo tempo, a considerar o lugar inevitável dos pedagogos surdos no cenário educativo, a se assegurar da qualidade das "babás linguísticas" empregadas para ensinar às crianças surdas e a questionar as modalidades de aprendizado em termos distintos das outras línguas, minoritárias ou não. Isto posto, as consequências das escolhas educativas em relaçáo à escolaridade dos surdos, à transmissão atípica de sua língua primeira, por um lado, ou à aquisição de uma LSF "exótica" por não surdos, por outro lado, pleiteariam antes em favor de uma didática que lhe seja específica. Essa atipicidade das línguas sinalizadas constitui uma razáo suficiente para criar um novo ramo da didática das línguas e das culturas. Retomaremos mais adiante esse ponto.

\section{A virada do século XXI na França}

\footnotetext{
${ }^{23}$ Muitos autores preconizam que não nos apoiemos obrigatoriamente na consciência fonológica para o acesso à escrita. O primeiro foi provavelmente Foucambert e os trabalhos da AFL que o seguiram; depois, Goigoux (em Les élèves en grande difficulté de lecture et les enseignements adaptés [Os alunos em grande dificuldade de leitura e os ensinos adaptados], CNEFEI, Suresnes, 2000) ou Cambien (em Apprendre à lire à l'enfant sourd [Ensinar uma criança surda a ler], CNEFEI, Suresnes, 2000), que se apoia em Richaudeau, enquanto trabalhos como os de Dehaene são cada vez mais controvertidos. É o que mostra Vanbrugghe (tese em curso na Universidade de Nanterre).
} 
Enquanto vagas para pesquisadores surdos foram abertas no exterior desde os anos 1970, a primeira vaga de "mestre de conferência associado em tempo parcial" (PAST) para professor surdo sinalizador somente foi aberta em 2000, na Universidade de Paris 8, em Ciências da linguagem. Antes da criação de tais vagas, nenhum verdadeiro currículo universitário em LSF pôde existir, ainda que a língua de sinais fosse eventualmente um objeto de estudo nessas mesmas universidades.

Paralelamente, e sem que uma didática da LSF seja ainda estabelecida, programas pioneiros de formação se desenvolvem na França apoiando-se nas reflexóes assumidas principalmente pelas associaçôes do movimento surdo. É por meio de pesquisas-ação que os pesquisadores, os atores da educação dos surdos e a comunidade sinalizadora poderão se interrogar acerca da normalização dessa língua, que não tinha sido anteriormente objeto de nenhum ensino universitário, e também acerca de seu ensino, enquanto língua segunda, inicialmente, e somente depois, um pouco paradoxalmente, enquanto língua primeira.

Há uma década o reconhecimento da LSF parece ter sido alcançado e seu ensino ter progredido, mas persistem ainda obstáculos estruturais freando a abertura das turmas em LSF. Entre outros, a grande heterogeneidade nas turmas de LSF, seja o projeto claramente bilíngue ou não, é reforçada pela falta de visibilidade de tais estruturas. Essas turmas são ainda mais marginais no ensino francês do que as turmas de línguas regionais. As famílias não sabem o que escolher nem onde existem estruturas correspondentes, de modo que determinados alunos surdos chegam a classes bilíngues já com seus cursos iniciados, ou após um início de percurso escolar que os colocou em situação de fracasso, com um atraso de linguagem (atraso em LSF também, considerando-se que sempre se pensa somente no atraso de linguagem em francês). Recentemente, algumas raras pesquisas foram feitas em francês língua segunda ${ }^{24}$ para os surdos (HAMM, 2010; PERINI, 2011) ou em aquisição da leitura em um ensino em $\mathrm{LSF}^{25}$.

\footnotetext{
${ }^{24}$ No contexto da Educaçáo nacional na França, o FLS é apresentado como língua determinante para a socialização do aprendiz surdo.

${ }^{25}$ Burgat (tese defendida em Paris 8, em 2007). Ver também Besnard (surdo), "Comment construire un pont entre LSF et français pour favoriser l'émergence de l'écrit chez l'enfant sourd scolarisé en classe maternelle bilingue?", [De que modo construir uma ponte entre LSF e francês para favorecer a emergência da escrita na criança surda escolarizada em classe maternal bilíngue?], dissertação de M2 [Master 2] da Universidade de Paris 8, defendida em 14 de setembro de 2017.
} 


\section{Um conjunto de reflexóes de ordem epistemológica}

O estudo da LSF e de seus locutores, especialmente quando esse estudo é desenvolvido conjuntamente com os referidos locutores, configura simultaneamente um desafio científico e uma boa questão epistemológica, pelo fato de exigir que se ajustem, e mesmo que se modifiquem, conceitos já estabelecidos. Desde o "despertar surdo", os pesquisadores interessados na língua de sinais e os surdos caminharam juntos ${ }^{26}$. A força dessa cumplicidade se deve certamente ao fato de que a surdez se comporta como um catalisador eficaz da reflexáo: ela questiona conceitos falsamente evidentes.

\section{Evidências a reconsiderar}

Quem não conhece a surdez se surpreende diante da ideia de que a deficiência de seus protagonistas "desaparece" se eles utilizam a língua de sinais, o que não é o caso em outras situações de deficiência.

Paralelamente à questão das competências comunicacionais, analisar as interaçôes linguageiras entre surdos obriga a reinterrogar elementos táo fundamentais quanto os que se seguem: o que é uma "língua", seja ela constituída de sons ou não; o que define a língua dita materna e igualmente a língua "primeira"; o que compreende o "domínio" de uma língua, quando seus protagonistas estáo impedidos na conversação.

$O$ fato de querer garantir uma escolaridade a uma criança surda exige reajustes de fundo no ato de ensinar face à necessária escolha da língua para a modalidade oral: até que ponto deve um professor aceitar estabelecer trocas com seus alunos em uma língua necessariamente lacunar, por falta de melhor solução? Como pode o professor apoiar-se em uma língua confortável, e a que preço para a criança, mas também para a sociedade? $\mathrm{O}$ que supõe a utilização de uma língua gestual sem escrita, no contexto de uma escolarizaçáo que deve, contudo, contribuir para construir competências de leitor? Um "professor para surdos" deve ele também ser surdo? O que significa acompanhar os aprendizados de um aluno surdo se não se pode compreendê-lo?

Questionemo-nos também acerca daquilo a que deve responder uma formação profissional adequada, que levaria em conta igualmente os 
desvios ligados à avaliação das aquisições de um aluno surdo, na medida em que o avaliador se apoiaria sobre uma língua mal instalada para avaliar competências disciplinares outras que não as competências referentes à língua. Com efeito, trata-se aí exatamente de avaliar o conteúdo e os conhecimentos de um modo que não seja utilizando competências verbais.

Ao mesmo tempo, considerar o ensino de um público dito deficiente auditivo exige que se questione o que está compreendido no próprio princípio de uma noção como "a situação de deficiência" e que se examinem muitas das ações aí incluídas: educar, ensinar, dar assistência a um aluno... e mesmo o que está incluído no ato de traduzir, por exemplo, em situação pedagógica. Assim, as incidências da surdez levam a reconsiderar muitos dos grandes conceitos convocados no campo educativo, começando pela diferença entre "aquisição" não guiada e "aprendizado", que supóe a intervenção de um profissional ${ }^{27}$.

Para retomar aspectos mais linguísticos, estudar uma LS obriga também a reconsiderar pontos fundamentais como a fonologia, a sintaxe, o arbitrário. Graças aos trabalhos de Cuxac, um esclarecimento da definição original do arbitrário do signo linguístico interveio em relação ao(s) sentido(s) em que o empregavam os autores depositários do Curso de Linguistica Geral, de Saussure, fundador da linguística moderna. Assim sendo, "icônico" não se opóe a "arbitrário", uma vez que se trata tão somente de uma particularidade ligada ao canal (audiovocal versus viso-gestual).

Em uma outra ordem de ideias, as pesquisas de Courtin evidenciaram a necessidade, no caso das crianças surdas, de orientar as observaçôes sobre o deficit de atenção para a flexibilidade de atenção. A pesquisa de Leroy recolocou em questão o uso do termo "bilíngue" aplicado a certas práticas educativas para as crianças surdas. Geffroy destacou uma discriminação estrutural em seus trabalhos sobre o acesso dos surdos às profissóes do ensino, apesar de um modo de recrutamento que pretendia ser náo discriminatório, o que exige uma reflexão sobre as condiçôes de inclusão para não provocar uma exclusão do interior. Burgat (2009) e, depois, Vanbrugghe (tese em curso) reexaminam o papel da vocalização e o lugar da consciência fonológica no ato de leitura, levando-nos a considerar a competência do leitor sob um novo ângulo.

\footnotetext{
${ }^{27}$ No início dos anos 1980, o pesquisador americano Krashen opõe a aquisição natural de uma língua em contexto de imersão à aprendizagem que tem lugar em ambiente escolar. Essa dicotomia terminológica foi abandonada em proveito do estudo das aprendizagens "implícitas" e “explícitas”, sejam elas em meio escolar ou em situaçáo de imersão (COSTE, 1992).
} 
Enfim, fazer da língua de sinais um objeto de estudo, acima de tudo pelo fato de que seus professores podem ser surdos sinalizadores e formados principalmente pelo meio associativo, interroga as políticas linguísticas francesas e serve para redefinir os conceitos essenciais como os de plurilinguismo, diversidade cultural, interação pedagógica, aprendizagem em pares. A esse respeito, lembremos ser possível uma aproximação entre a história das turmas de línguas regionais ${ }^{28}$, o que inclui as questóes de formação dos professores das escolas atuais nessas turmas e as turmas bilíngues em LSF ${ }^{29}$, hoje todas reconhecidas pela Educação nacional.

Essas observaçóes mostram que seria lamentável privar-se do olhar que uma didática específica das LSF poderia oferecer.

\section{Levar em consideraçáo um modo de pensamento visual}

"Dizer mostrando" é inerente à surdez ${ }^{30}$, e essa intenção semiótica tem lugar espontaneamente em uma interação pedagógica conduzida por pedagogos surdos, porque sua vivência da surdez lhes permite mobilizar ou reavivar a capacidade de gerar sentido em uma modalidade viso-gestual acessível a todos e, em particular, a um aluno surdo. Eles adotam, com efeito, um funcionamento em analogia com a experiência perceptivoprática, em razão de referências proprioceptivas específicas. É por essa razão que os surdos contribuem nas equipes com muito mais do que apenas sua língua; eles trazem seu conhecimento experiencial da surdez, o que não pode ser oferecido pelos professores ouvintes (COURTIN, 2002): constatam-se, entre outras coisas, a utilização de estratégias pedagógicas e uma postura educativa atípica (LEROY, 2010). Desse modo, sempre que possível, elementos de observaçáo levando em conta as similaridades e as variaçôes entre os dispositivos de ensino em LSF com professores surdos ou

28Para mais informação, ver Hélot e Erfurt (2016).

${ }^{29} \mathrm{Cf}$. decreto de 11 de julho de 2007 , que fixa os programas de ensino da língua de sinais francesa na escola primária e no colégio [ensino fundamental], publicado no Journal Officiel de 17 de agosto de 2017.

${ }^{30}$ Falamos aqui da intenção semiótica (CUXAC, 2000), que também é revelada pela análise das línguas de sinais emergentes (LSE) instituídas por indivíduos surdos vivendo integrados exclusivamente em ambiente ouvinte (cf. os trabalhos de Fusellier-Souza, 2004). Isso comprova o fato de que seres humanos privados de um acesso direto a um modelo linguístico estabelecido são capazes de construir um sistema de comunicaçâo gestual linguisticamente organizado. Esse sistema de comunicação, baseado no canal viso-gestual, parece satisfazer às funçôes centrais presentes na linguagem humana. 
ouvintes sinalizadores e os outros dispositivos poderiam constituir o objeto de pesquisas aprofundadas ou serem utilizados nos protocolos de enquete dos pesquisadores em ciências da educação.

Para além das disparidades que podem existir entre diferentes línguas de sinais (microcomunitárias ou individuais, no caso das línguas emergentes), pesquisadores como Sallandre, Garcia e Fusellier evidenciaram a originalidade da concepção (por imagens) e a apreensão (visual) do mundo manifestada pelos surdos, capazes de coconstruirem espontaneamente uma língua viso-gestual rica com seus próximos, contanto que estes se mostrem receptivos. Só de observar a emergência de uma língua natural em um locutor surdo que náo tivesse tido contato com sujeitos sinalizadores na escola ou em seu meio ${ }^{31}$, vislumbra-se o quanto teríamos a aprender acerca da pedagogia própria aos surdos.

Tomar em consideração o modo de pensamento dos surdos implicaria que uma autêntica didática da LSF alimentaria também a pesquisa em ciências da educação, pois, com a presença da LSF no ensino - muito mais do que apenas com as aulas de LSF -, desenvolve-se um verdadeiro centramento da pedagogia no sentido. Isso significaria também considerar as pessoas ditas deficientes como sendo "capazes, mas de um modo diferente", ensinando-nos a coconstruir sentido para além da simples atividade verbal (oral ou sinalizada). Pesquisas aprofundadas poderiam, dessa forma, exercer algum impacto sobre a escolarização de todos os outros públicos e sobre a formação dos profissionais.

\section{Sobre o interesse didático do estudo das línguas sinalizadas}

Adotamos, como princípio, que o papel de toda didática é observar fatos de ensino e, eventualmente, construir conceitos capazes de descrevêlos.

No caso da aquisição de uma língua estrangeira, observa-se a construção de um lecto, isto é, uma variante linguística de aprendiz, principalmente no início. Mesmo se a aquisição se faz em ambiente que se aproxime de uma imersão e em tenra idade, uma interlíngua transitória bastante similar poderá perdurar mais tempo para alguém que tenha problema de audição. Apesar da reeducação fonoaudiológica, a construção de um lecto da língua

\footnotetext{
${ }^{31}$ As criaçóes gestuais nascidas do processo de iconicização da experiência tornam-se em alguns anos línguas de sinais emergentes, como o descreveu Fusellier-Souza (2004).
} 
da escola será perpétua para uma criança surda, mesmo que a utilização dessa língua seja intensamente estimulada em família.

Em outros países, tais questóes resultaram na criação de deaf studies. A iniciativa foi de Padden e Hemphris em meados dos anos 1980, ambos surdos e pesquisadores em antropologia em Gallaudet, esse grande campus de Washington que há muito tempo oferece aos surdos, sinalizadores ou não, a possibilidade de fazer seus estudos em língua de sinais, desde a escola maternal até a universidade (DALLE-NAZEBI, 2006). A ideia de um Centro de deaf studies se multiplicou no decorrer dos encontros e dos colóquios, estruturando-se bastante rapidamente na Alemanha (em Hamburgo) e no Reino Unido (em Bristol). Na França, a ideia não floresceu, mas influenciou as representaçóes que as pessoas surdas tinham de si mesmas e, também, aqueles que acompanhavam o "despertar surdo", iniciado, lembremo-nos, com uma viagem a Gallaudet organizada por Mottez no final dos anos $1970^{32}$. Em torno dos deaf studies, encontra-se um microcosmo de pesquisadores e atores do meio surdo situados em uma abordagem socioantropológica, estando ao mesmo tempo ligados a uma maior distância aos outros especialistas de cada disciplina representada.

É preciso observar que, nos países escandinavos, a surdez está principalmente localizada no campo dos disability studies, porque se situa no campo da deficiência. Ora, sendo a LS reconhecida e a acessibilidade assegurada em todos os momentos da vida, a presença dos surdos na pesquisa se difundiu, e, assim, pessoas do campo e pesquisadores podem apoiarse reciprocamente. Essa perspectiva, mais socioantropológica, constitui a vertente não patológica da surdez e posiciona de imediato os surdos como pessoas "capazes, mas de um modo diferente", em plena adequaçáo com as recomendaçôes internacionais atuais.

Náo estamos na mesma situação na França ${ }^{33}$, onde uma LS náo pode ser vista como um dos elementos constitutivos de uma cultura própria dos surdos, mesmo que a LSF já tenha adquirido direito de cidadania. As representaçóes sociais em relaçáo aos locutores surdos como, acima de tudo, pessoas deficientes estabelecem uma diferença fundamental porque modificam completamente o olhar dirigido ao aluno surdo e, na prática, o tratamento da questáo dos surdos, tanto no campo das políticas educacionais quanto no da pesquisa.

32Minguy (2009).

33Ver os trabalhos de Ebersold (2013). 


\section{Onde situar a LS na didática?}

Apesar de existir há séculos, a língua dos surdos é antes de mais nada uma língua de "tradição oral ${ }^{34 "}$ que, com períodos menos favoráveis do que outros, se transmitiu no interior das escolas especializadas e quase exclusivamente fora dos tempos de aula. Considerando que, na melhor das hipóteses, crianças e adultos surdos apenas receberam o simples direito de uso dessa língua, ela evoluirá sem uma grade de avaliaçáo até o início do século XXI, com a criação, em 2002, de um referencial segundo o princípio do Quadro Europeu Comum de Referência para as línguas.

Como outras línguas de tradição oral, o estudo da LSF poderia ter se contentado com um lugar no interior das ciências da linguagem, mas nesse campo, assim que uma língua é ensinada e se torna mesmo língua de ensino, seus locutores e aqueles que a aprendem têm vontade e necessidade de pensar sua própria didática. Para isso, foi necessário em um primeiro momento descrever a LSF, assumindo-se o risco de dar conta da "fonologia", do léxico e da sintaxe de uma língua gestual com instrumentos comparáveis àqueles utilizados para as línguas orais. Contudo, a reflexão das principais associaçôes do "despertar surdo" tinha se comprometido não somente com a difusão da LSF, mas também imediatamente com a construção de saberes de tipo escolar por meio dessa língua ${ }^{35}$. Ao discutir sobre as aprendizagens através de uma língua gestual, o debate se orientou muito rapidamente em direção à luta contra a subinstrução à qual estão confinados todos aqueles que não podem interagir com uma língua audiovocal, como foi lembrado anteriormente. Desde então, os pedagogos surdos insistentemente convocam os pesquisadores a criar um campo didático consagrado à LSF, a fim de entrarem em seguida com eles em algo que se poderia muito bem considerar um círculo virtuoso, sem esquecer que, com diferentes graus de implicação, cada um sustenta uma visão complementar dos mesmos fenômenos. Mas a didática das línguas e das culturas demora a tomar a LSF em consideração de um modo que não seja marginal. A tese de Morillon em 2001 não teve muita repercussão. Foi preciso esperar os trabalhos de Mugnier, em 2006, e os de Leroy, em 2010, para que a relaçáo professor / aprendiz fosse analisada em seus aspectos didáticos, levando em conta o uso da LSF. Assim, náo

\footnotetext{
${ }^{34} \mathrm{~A}$ escolha de termos emprestados do campo da "oralidade" aplicados às línguas gestuais está ligada ao fato de que tais línguas são utilizadas em face a face e de que, até a utilização do vídeo, não havia qualquer possibilidade de registro de traços dessas línguas.
}

${ }^{35}$ Minguy (2009). 
seria lamentável que não se reunissem todas as pesquisas desenvolvidas por pesquisadores constatados ou potenciais vindos de horizontes diferentes? Nem que fosse apenas por essa razão, já seria hora de engendrar uma didática específica para as LS.

A questão da educaçáo dos surdos pode não se restringir apenas à questáo do funcionamento ou do domínio da língua, pelo simples fato de que a linguística convoca frequentemente outras disciplinas. Desse modo, alguns estudos se interessaram pouco a pouco pela vertente praxeológica: observação das práticas, modalidades de transmissão de uma língua a priori original por surdos que dela faziam seu ofício, identificação dos contextos de utilização da LSF, análise da ação e programas de formação para a ação. Dito de outro modo, ainda que os pioneiros do bilinguismo na educação dos surdos tenham desejado ao mesmo tempo formaçáo para os novos professores atuando há pouco tempo no campo e para os futuros pedagogos surdos, a ancoragem universitária não se iniciou no campo das Ciências da educação.

Entre a primeiríssima proposta de formação profissional de professores acessível aos surdos, concebida pela associaçáo 2LPE e apresentada ao ministério da Educação nacional em 1982 (posteriormente transformada pelo CNEFEI de Suresnes em 1986 para formar "peritos em LSF" surdos), e a primeira Licenciatura profissional aberta em 2004, outros programas de formação promovidos por associaçóes tinham sido implantados. Citemos, entre outros, o DPCU "especialização ensino da LSF", criado pela associação Visuel-LSAF em 2000, em parceria com a universidade Paris 8. Observe-se que a licenciatura profissional intitulada "Ensino da LSF em ambiente escolar", iniciada em 2004 e integrante da Formaçáo permanente da universidade Paris 8, é o primerio currículo universitário voltado para o público sinalizador.

Essa atividade de formação em que o ensino é integralmente feito em LSF - ou interpretado - e com a possibilidade de entrega de trabalhos em LS-vídeo proporcionou, desse modo, uma formaçáo profissional que diplomava professores surdos sinalizadores e, ao mesmo tempo, dava o reconhecimento necessário ao exercício da função na escola. Contudo, no campo da educação, os atores surdos, ainda que indispensáveis, sofrem sempre para ocupar o lugar que merecem e se esgotam nessa tarefa, sem poderem centralizar seus trabalhos ou se coordenar. Eis o que se destaca dos diferentes encontros de associaçóes ou das diferentes jornadas de estudos do meio surdo: universidades de veráo $2 \mathrm{LPE}$; colóquio "LSF: ensino, 
identidade profissional e programa”, em outubro de 2006; jornadas da AFFELS; encontro sobre a educação bilíngue (INS-HEA, outono de 2016), etc.

Em junho de 2006, a LSF foi introduzida como possível disciplina opcional no exame de conclusão do ensino médio. Um programa oficial, uma definição de carga horária e um recrutamento de professores com certificação foram medidas implantadas entre 2008 e $2010^{36}$. Tudo isso conduziria a um balanço encorajador. Porém, essas medidas aplicadas inicialmente no ensino secundário regular dizem respeito, por essa razão, majoritariamente a alunos ouvintes; enquanto isso, há muito poucas turmas de LSF, e os alunos surdos tiraram pouco proveito delas, por não terem praticamente cursos referentes a essa língua. Um novo paradoxo vem surgindo: os pais em geral são entusiastas da ideia de que seus filhos aprendam a LSF e que o sistema lhes permita escolhê-la como língua opcional, pois estão convencidos de que isso lhes trará benefícios, podendo sempre ser-lhes útil; enquanto isso, os pais de crianças surdas se engajam em uma luta permanente para que seus filhos e eles mesmos tenham um acesso facilitado e menos parcimonioso a essa língua que é tão crucial para eles ${ }^{37}$. É por essa razão que Meynard (2013, p. 34), entre outros, propóe que estejamos alerta, pois não se deveria "infelizmente pensar que o sombrio destino reservado à LSF pertence a partir de agora a um passado que teríamos definitivamente superado".

É certo que a pesquisa e as atividades de formação universitárias avançam. Estudantes surdos têm cada vez mais acesso aos estudos superiores e refletem sobre a maneira de acessar o conteúdo do ensino em $\mathrm{LSF}^{38}$, e isso apesar da falta de meios para se beneficiarem totalmente de uma interpretação em LSF. Paradoxalmente, poucas crianças surdas têm acesso às raras turmas bilíngues LSF / francês escrito permitindo um ensino de "qualidade" em LSF (apenas 1 a 2\% dos alunos surdos, segundo a Associação Nacional dos Pais de Crianças Surdas - ANPES ${ }^{39}$ ).

A vinculação indecisa dos trabalhos referentes à língua de sinais é também o reflexo do estatuto da língua e de seus locutores. A questâo

\footnotetext{
36Uma reorganização ocorreu em 2017.

${ }^{37}$ Mesmo o Bureau International d'Audio-Phonologie (BIAP) recomenda, desde 2003, uma exposição precoce às duas línguas para todas as crianças surdas.

${ }^{38}$ Seminários STIM organizados pelo setor de estudantes da FNSF e da Etudiant's 31, que reúnem estudantes surdos, intérpretes, professores, linguistas etc., em torno de uma reflexáo sobre o léxico específico em LSF.

39Para mais informação, ver Dalle (2005) ou consultar http://anpes.free.fr/Creation/ modeleConfEducBil.pdf.
} 
do recrutamento dos professores de LSF não foi resolvida, senão muito parcialmente, pela criação de um concurso da Educação nacional, o CAPES de LSF, a partir de 2010, fato simbolicamente relevante.

Contudo, as necessidades do campo são consideráveis, mas os números não as traduzem adequadamente, de modo que os profissionais já atuando no campo ou em formação buscam referências junto às universidades e o fazem em uma rede europeia ou mesmo internacional, uma vez que as LS têm essa abertura e essa facilidade de interação.

\section{Cumplicidade entre o campo e a pesquisa}

Em geral, toda didática parte do campo ocupado pelos profissionais nele em ação, os quais abrem posteriormente um espaço em sua prática para os profissionais da didática, solicitando-os em seus programas de formação. A emergência recente da didática do Francês Língua Estrangeira (FLE) é um exemplo bastante característico desse processo: a entrada do FLE na universidade e a profissionalização do ofício de professor de FLE ocorreram nos anos 1980, apoiando-se em dois organismos essencialmente originados no campo, o Bureau d'enseignement de la langue et de la civilisation françaises à l'étranger (BELC $)^{40}$ [Escritório de ensino da língua e civilização francesas no exterior] e o Centre de recherche et d'étude pour la diffusion du français $(\mathrm{CREDIF})^{41}$ [Centro de pesquisa e de estudo para a difusão do francês].

Com a LSF, instalou-se uma retórica inversa que não partiria do campo para contribuir para o nascimento da didática. Em um primeiro momento, estudos e pesquisas se abriram para os surdos decididos a reconquistar o campo. Conferências ou atividades de formação específica estiveram enfim

${ }^{40} \mathrm{O}$ BELC, fundado em 1959, recebeu seu nome atual em 1965, no momento de sua vinculação, como seção especializada, ao Centro Internacional de Estudos Pedagógicos (CIEP). Encontra-se na origem da revista Le français dans le monde, em 1961, e de um estágio de verão regular que, ao longo dos anos, evoluiu em funçấo do ambiente teórico e das necessidades de seu público. É interessante notar que, progressivamente, os campos disciplinares abordados se ampliaram.

${ }^{41}$ O CREDIF, organismo público francês de pesquisa científica criado também em 1959, tinha por objetivo realizar pesquisas e publicaçôes sobre o ensino do francês língua estrangeira. A demanda ministerial inicial era estabelecer uma progressão lexical e sintática que facilitasse a difusão do francês no exterior, em resposta a uma recomendação da Unesco de facilitar a educação de massa nos países em vias de desenvolvimento. A criação das carreiras universitárias de FLE levou o ministério a suprimi-lo em 1996, e seus pesquisadores foram redistribuídos em outras unidades do IENS de Saint-Cloud ou ingressaram em diversas universidades. 
acessíveis, encorajadas pelos trabalhos de pesquisadores ainda marginais que se deslocaram muito para sustentar as iniciativas isoladas das associaçôes.

Reconhecer a competência daqueles que trabalham no campo permitiu justificar num segundo momento a implementação de qualificaçóes pensadas para eles (KERBOURC'H, 2006; LEROY, 2010; GEFFROY, 2015). As primeiras atividades de formação das associaçóes no âmbito do ensino da língua de sinais (para profissionais surdos ou para as famílias), ou no âmbito da interpretação para os profissionais ouvintes e não sinalizadores, não se apoiavam em nenhuma experiência anterior: os que trabalhavam no campo iam tateando, e os especialistas que podiam fornecer um apoio teórico eram raros. Depois, um vai e vem pouco a pouco se encadeou entre os que exerciam a prática e os especialistas da didática.

Nos debates referentes às escolhas de sociedade transversais em torno da escola inclusiva, pesquisadores em LSF e profissionais da surdez mostram-se cautelosos quando se trata da inclusão dos alunos surdos. Com efeito, se repensar o equilíbrio entre classes de inclusão e classes específicas deve contribuir para uma diferenciação ponderada, o impacto crucial da escolha da língua de ensino pode comprometer a missão principal da escola: construir para as crianças surdas aprendizagens à altura de suas capacidades, à semelhança de todas as outras.

Dito isso, longe de constituir um fechamento sobre a comunidade surda e sua língua de predileçấo, a didática da LSF daria lugar à diversidade de pontos de vista, incluídas pesquisas voltadas para as representaçôes da deficiência em geral e outras que, a seu turno, se voltam para as políticas educativas ou linguísticas. Surdos sinalizadores e ouvintes aí trabalhariam juntos, a acessibilidade seria muito mais bem assegurada (e sistematicamente prevista) do que em qualquer outro lugar.

\section{Didática e bilinguismo surdo}

Contrariamente à didática das línguas orais, uma didática da LS exige pensar não apenas o ensino dessa língua, mas também a abordagem particular necessária às outras disciplinas pelo fato de serem ensinadas em LS, sendo a articulação ideal o bilinguismo na pedagogia.

A construção de uma didática da LSF reenvia certamente à questão da padronizaçáo da língua, e os recentes programas do Ministério da Educação nacional nos fazem tomar consciência de que a LSF não foge à coerção da 
norma. Contudo, não se poderia hoje pensar em reservar para essa língua um lugar baseado no uso de seus locutores e da comunidade sinalizadora? Desse modo, ela seria não mais um belo objeto de estudo atípico, e sim uma língua de pleno direito, contribuindo ao mesmo tempo para o reconhecimento dos direitos de qualquer pessoa surda que se comunique por meio da língua de sinais, sejam quais forem sua idade, seu percurso de vida e seu lugar na vida social.

Ainda que criar um campo próprio para essa língua e para a comunidade que a fala incida profundamente na formação dos profissionais da educação, isso não impóe uma visão focalizada na surdez. Os avanços decorrentes da reflexão sobre a educação dos surdos podem irradiar até às adaptaçôes pedagógicas e contribuir para construir uma escola mais inclusiva que não mais tenha a situação dos surdos como preocupação e, também, não lide com os alunos por categoria. Isso também supóe que os diferentes trabalhos circulam até as atividades de formação dos professores.

Seria preciso todo um artigo para abordar o problema dos planos de formaçáo e dos conteúdos destinados a profissionais do ensino bilíngue para os surdos. Faremos aqui apenas uma breve apresentaçáo da questão:

- a preparação para o CAPEJS (Certificat pour enseigner dans les établissements du Ministère de la Santé [certificado para ensinar nos estabelecimentos do Ministério da Saúde]) em Chambéry foi aberta para os surdos há muito tempo. Porém, os professores bilíngues (e, muito particularmente, os professores surdos) não encontram aí nenhum benefício pelo fato de a formação proposta não considerar especificamente o ensino das diferentes disciplinas em LSF para os alunos surdos;

- o INS-HEA de Suresnes (o centro de formação para os professores especializados da Educação nacional) propóe um currículo que leva à "especialização", enquanto os professores das turmas bilíngues gostariam de estar mais perto dos professores "comuns", com a diferença de que estes utilizam uma outra língua de ensino. A preparação para o Certificado de especializaçáo e os estágios de formação continuada são reservados apenas para os professores já efetivos, o que deixa pouca esperança para os surdos, que são frequentemente contratados ou se encontram em situaçáo ainda mais precária ${ }^{42}$.

Além disso, é preciso considerar flutuaçóes da Educaçáo nacional em seus posicionamentos a respeito do ensino bilíngue junto aos alunos surdos.

${ }^{42}$ Contudo, cabe mencionar alguns professores surdos sinalizadores recentemente nomeados para ocupar um cargo como efetivos. 
A título de exemplo, comparemos dois BO [Bulletin officiel], o de 4 de setembro de 2008 ( $\left.{ }^{\circ} 33\right)$ e o de 24 de junho de 2010 ( $\left.n^{\circ} 25\right)$, em relação a três pontos:

10) o estatuto pedagógico da LSF: o documento de 2008 coloca claramente o domínio da LSF como anterior às outras aprendizagens, enquanto o de 2010 retomava uma abordagem incompleta e imprecisa, atribuindo as dificuldades de leitura dos surdos à "quase impossibilidade de recurso ao código de correspondência grafofonético" ${ }^{43}$. Nenhuma dessas duas abordagens é verdadeiramente baseada em resultados de pesquisa ou no estudo das políticas sociais e linguísticas adotadas por outros países que nos mostram outras posturas educativas quanto à deficiência e quanto a suas línguas minoritárias - dentre as quais se encontra a língua de sinais local ${ }^{44}$.

$2^{\circ}$ ) os polos LSF: o documento de 2008 os concebe como "percursos bilíngues em LSF". Eles não mais existem enquanto tais, uma vez que o segundo documento, ao renomeá-los "Polos de acompanhamento para a escolarização dos alunos surdos (PASS)", amplia consideravelmente sua missão ao conjunto dos "dispositivos pedagógicos e tecnológicos que permitem a todos os jovens surdos, seja qual for o modo de comunicaçáo escolhido por suas famílias, cursar um ensino o mais próximo possível de uma escolarização comum, sem se focalizar apenas na LSF". Com a criação do cargo - um tanto ambivalente - de mediador pedagógico ${ }^{45}$, que simultaneamente é professor formado, intérprete confirmado e tem uma sólida formação na assunção dos alunos com dificuldade, que lugar podem os professores surdos ocupar para trazer respostas aos atores do campo? Como se passam as coisas hoje, com a criação dos $\mathrm{PEJS}^{46}$ (Polos de ensino para jovens surdos)?

\footnotetext{
${ }^{43}$ Acrescentemos, porém, para nuançar nossas palavras, que a recente revisão dos programas (Decreto de 11 de julho de 2017, que fixa "os programas de ensino da língua de sinais francesa na escola primária e no colégio [no ensino fundamental]”, publicado no JO de 17/08/2017) parece ter esclarecido o lugar e o papel da LSF nos currículos bilíngues. O impacto dessas escolhas poderá assim ser estudado dentro de alguns anos por meio de uma didática da LS.

44 Por exemplo, a Suécia, em 2009, aprovou uma modificação da lei que reconhecia as minorias linguísticas em seu território. Há cinco línguas minoritárias nacionais, desde $1^{\circ}$ de janeiro de 2010: o finlandês, o iídiche, o meänkieli, o romani e o lapão (ou sámi). Por outro lado, proporcionar o acesso da língua de sinais sueca ao público surdo e aos que se tornaram surdos (mesmo tardiamente) é considerado como sendo da responsabilidade coletiva.

${ }^{45}$ Circular $n^{\circ} 2010-068$ de 28 de maio de 2010, do BO no 25 de 24 de junho de 2010 do Ministério da Educação Nacional.

${ }^{46}$ Cf. circular $\mathrm{n}^{\circ}$ 12017-011 de 03/02/2017, publicada no Bulletin officiel de l'Education nationale $\mathrm{n}^{\circ} 8$, de 23/02/2017.
} 
3o) enfim, a noção de bilinguismo: falar novamente no $\mathrm{BO} \mathrm{n}^{\circ} 25$ de 2010 de "modo de comunicação" ou de "comunicaçáo bilíngue", ao invés de educação bilíngue, terminologia empregada no $\mathrm{BO}$ de 2008, gera confusão. Constata-se no campo, no caso de alunos integrantes de um dispositivo bilíngue no qual seus colegas seguiram o currículo regular desde as classes primárias, as dificuldades que eles mesmos tiveram, assim como os professores.

A realidade do campo mostra com frequência um ensino para os surdos realizado em língua francesa, com o recurso de uma LS veicular e, quando possível localmente, uma ou duas horas semanais de curso de LSF. A lógica da inclusão generalizada em direção à qual se orienta a política de escolarização das crianças surdas, assim como para toda criança tida como carecendo de necessidades educativas particulares, conduz a uma individualização das respostas. $\mathrm{O}$ princípio de diferenciação não é em si condenável, mas, aplicado desse modo, ele negligencia uma adaptação pedagógica maior que a pedagogia bilíngue tem como perspectiva: construir as aprendizagens com uma língua de ensino acessível e utilizada em um grupo de pares.

No contexto de uma didática da LSF constituída, as escolhas educativas seriam feitas com base em critérios mais objetivos do que passionais, com conhecimento de causa. A observaçáo das especificidades do ensino para crianças surdas nos oferece uma boa oportunidade de pôr em prática o princípio de centramento nas necessidades do aprendiz ${ }^{47}$ para fazêlo avançar em suas aquisiçóes, ao invés de manter um ensino "descendente". É para melhor responder a essas necessidades que o professor deve procurar compreender e respeitar o modo de aprendizagem dos aprendizes surdos - e das crianças surdas, em particular -, integrando sua língua e sua cultura. Em geral, uma tal abordagem visa à emancipação cognitiva da criança: "Ora, a pedagogia é justamente a recusa simultânea do ensino programado, que reduz o ser a uma máquina que aprende, e da instauração de refúgios libertadores, onde se aguarda passivamente a maravilhosa eclosão de "aptidóes inatas". O pedagógico é o esforço para fugir dessas duas tendências e construir situaçōes que são, ao mesmo tempo, verdadeiramente estruturadas com fortes mediaçôes culturais e que acompanham a emergência de um sujeito. "Fazer

${ }^{47}$ Temos, desse modo, a íntima convicção de que a pedagogia dos surdos tem tudo a nos ensinar, uma vez que a intenção semiótica dos locutores surdos cria a língua. "Dizer mostrando" é, desse modo, inerente à surdez, e essa emergência linguística se reflete nas interaçôes pedagógicas naturais entre surdos, já que o pedagogo surdo não hesita em partir em busca dessa mesma intenção semiótica na criança. 
para que o outro faça" - eis aí, desde Rousseau, a máxima da pedagogia” (MEIRIEU, 2009).

\section{E se tentássemos definir a didática da LSF?}

Uma didática da LSF está em seus inícios. Sua história foi escrita, à semelhança da história do reconhecimento dessa língua, a partir do trabalho das associaçóes nascidas com o "despertar surdo" e dos primeiros pedagogos bilíngues $^{48}$. A vertente da pesquisa se constituiu em torno dos primeiros trabalhos universitários que acompanharam esse movimento desde os anos 1980 e, em seguida, por meio das dissertaçôes universitárias situadas na didática das línguas e das culturas, mas centradas especificamente na LSF: Munoz (DEA em 1997, em Paris 5), Morillon (tese de 2001), Geffroy (DEA em 1999), Hugounenc (DEA em 2003, em antropologia social, mas baseado na observação participante de um curso de LSF), Mugnier (tese de 2006), Leroy (tese de 2010). Contam-se ainda outras teses defendidas desde então, ou ainda em curso.

Um trabalho didático estruturado parece ser neste momento táo inevitável quanto o estudo linguístico da própria língua e pode se articular entre aqueles que buscam descrever essa língua, aqueles que observam seus usos entre utentes, aqueles que a transmitem, que pensam os programas, concebem progressóes pedagógicas ou criam suportes, e aqueles que a aprendem seja em imersão, seja com um professor. Ora, no cenário escolar atual, as turmas bilíngues representam menos de $2 \%$ das crianças surdas e sofrem frequentes contestaçôes ou são ameaçadas de fechamento.

No entanto, que o professor compartilhe a língua de sinais com os alunos surdos não resolve a questão do ensino disciplinar. Uma didática da LSF deverá, portanto, consagrar-se também às especificidades do ensino disciplinar para os alunos surdos, em particular no contexto de uma pedagogia bilíngue. Além disso, fora das turmas bilíngues, o professor é o principal parceiro desses alunos surdos na aquisição de competências comunicacionais, pragmáticas e socioculturais mobilizadas pelas crianças ouvintes ainda muito cedo, quando adquirem sua língua materna em um espaço que náo é o escolar.

Por exemplo, como a criança surda somente tem a experiência de uma comunicaçáo natural eficaz na modalidade viso-gestual, colaborar 
entre aprendizes e saber trabalhar em grupos são competências sociais que as crianças surdas podem melhor construir, sem obstáculo, na presença de uma LS compartilhada por todos, do que em ambiente regular, em razáo da perturbação das interaçóes, efeito colateral da surdez.

Tais aspectos pedagógicos não serão negligenciados se houver uma didática específica da LSF e se as trocas entre, por um lado, os surdos que atuam no campo e que têm uma experiência experiencial da surdez e, por outro, os ouvintes que atuam no campo puderem pensar a complementaridade entre a dimensão interacional própria dos surdos e as aprendizagens (GEFFROY, 2015). Talvez aí resida a marca de uma sociedade verdadeiramente inclusiva.

Os primeiros projetos de classes bilíngues tinham-se construído baseados no princípio das turmas de línguas regionais. As turmas bilíngues atuais não renegam essa filiação. Quer se trate do ensino em turmas bilíngues para surdos ou do ensino em turmas de línguas regionais, nota-se a presença de um efeito de ricochete entre uma transmissáo atípica da língua (regional, ou sinalizada) e a utilização dessa mesma língua para ensinar, porque ela se torna, nos dois casos, língua de ensino, o que não ocorria no passado.

Um ensino bilíngue que leve em conta especificidades da língua gestual ajuda a pensar a construção de conceitos disciplinares e de competências sem se focalizar nos aspectos lexicais. Se o enriquecimento linguageiro acarreta frequentemente um salto qualitativo no raciocínio, o aprimoramento das aquisiçóes também deve ser perseguido sem que as aquisiçôes sejam encapsuladas pelas palavras. Com efeito, pouco importa que os "sinais-palavras" da LSF (CUXAC; ANTIONORO PIZZUTO, 2010) não funcionem como etiquetas do mundo, como certas nomenclaturas estabelecidas para dar conta da terminologia da disciplina (GARCIA; DERYCKE, 2010), uma vez que a capacidade de memória linguística é mais extensa em LSF do que nas línguas orais (CUXAC, 2007). Uma das adaptaçôes mais importantes que os professores devem realizar consiste em dar sustentação às aquisiçóes desses alunos surdos por meio de estratégias pedagógicas não exclusivamente verbais.

É por essa razão que as atividades de formação da qual se beneficiam todos os professores, especializados ou náo, tanto em seus conteúdos quanto nas modalidades de trabalho, devem absolutamente ser acessíveis a todos, mesmo aos surdos. Constata-se que os pedagogos surdos estudam e centralizam suas práticas profissionais ${ }^{49} \mathrm{em}$ todas as atividades de formaçáo das quais

${ }^{49} \mathrm{O}$ surgimento de uma associaçáo reunindo esses profissionais prova essa necessidade de compartilhar saberes e uma experiência comum. Cf. https://affels.fr/. 
participam. Tudo se passa, portanto, em uma espécie de ação exclusiva entre pares, o que paradoxalmente lhes é com frequência criticado. Abrir todas as atividades de formação de perspectiva didática tornaria, assim, menos marginal essa pedagogia de LSF - e em LSF. Da mesma forma, os surdos que confirmam sua vocação de pedagogos ao longo de seu percurso de formaçáo podem assumir o papel de preceptor e referente linguístico, propondo uma forma de imersão em LSF ao ensinar outros conteúdos disciplinares, e o fazem sem tornar a atividade uma espécie de aperfeiçoamento linguístico. Com efeito, trata-se de uma espécie de aprofundamento cognitivo no qual os conceitos mobilizados são explicitados em uma modalidade viso-gestual. Quase todos os pioneiros do ensino bilíngue assim o fizeram desde o início, sem terem recebido qualquer formação para tal, e, além disso, criaram seus próprios suportes pedagógicos. Desde então prolongou-se e enriqueceu-se a reflexão a respeito.

A língua é indissociável da comunidade que a utiliza. No entanto, a ideia de uma cultura surda e de um pensamento visual ainda é com frequência contestada, de modo que o elo entre língua e cultura assume uma nuança particular no contexto da surdez, mesmo agora, quando a LSF tem direito de cidadania. Enquanto a didática de uma língua oral encoraja a participaçáo dos locutores nativos, não é sem reticências que o sistema francês busca se assegurar da participação de pessoas surdas. Há, certamente, razóes estruturais - que deveriam poder se atenuar ao longo do tempo pelo fato de que frequentar a escola até o final do ensino médio é, para os alunos surdos, uma verdadeira prova de esforço. Os surdos que concluem o ensino médio são, desse modo, raros, e somente 3 a $5 \%$ deles continuam seus estudos superiores ${ }^{50}$. Por essa razáo, poucos podem se apresentar nos recrutamentos de professores dentro dos dispositivos regulares ou se engajar em carreiras universitárias mais avançadas (GARCIA; BURGAT, 2016).

Finalmente, ainda que o tamanho da população em questáo pareça insignificante, uma vez que as crianças surdas representam algo em torno de $2 \%$ dos alunos em situação de deficiência ${ }^{51}$, as pesquisas sobre o ensino da LSF encontram-se fortalecidas relativamente ao grande desafio representado pela igualdade de oportunidades na escola que se recusa aos surdos, sem esquecer que isso pode levar a uma melhor ponderação das necessidades de

${ }^{50}$ Acerca dos obstáculos encontrados pelos surdos em seu percurso na universidade, mesmo possuindo os diplomas exigidos, ler E. Matsuoka (2016).

${ }^{51}$ Les panels d'élèves de la DEPP: source essentielle pour connaître et évaluer le système éducatif, "Les enfants en situation de handicap. Parcours scolaire à l'école et au lycée ", dezembro de 2017. 
qualquer outra criança em sua escolarização.

\section{Conclusáo}

Depois de uns quinze anos - de 1975 a 1990 - de desvendamento, de esperança, de desencorajamento e mesmo de algumas demonstraçóes de força, a língua viso-gestual, essa língua cuja natureza mesma reflete o modo de pensamento dos surdos, terá direito de cidadania na França. Graças a Markowicz e a Mottez, uma primeira coletânea de textos permitirá fazer um balanço do estado das pesquisas acerca das línguas de sinal e de tornálas conhecidas ${ }^{52}$, possibilitando, a partir de então, considerar os surdos de um outro modo que não por intermédio do filtro da deficiência e da anormalidade. Os militantes mais engajados tentaráo defender a ideia ainda inconcebível de que a surdez não é mais unicamente da competência do cuidado nem da reeducação, e que sua língua pode ser, por um lado, objeto de estudos e, por outro, língua de escolarização.

Por não ter encontrado um lugar em didática ou em ciências da educaçáo, o estudo da LSF enraizou-se em linguística, mesmo no caso dos trabalhos mais periféricos centrados nos programas de formação de intérpretes e na tradutologia ou na pedagogia bilíngue. Ao mesmo tempo, as pesquisas voltadas para a descrição e o uso dessa língua viso-gestual recolocaram em questão certos postulados da linguística, principalmente.

Atualmente, o estatuto das crianças surdas na escola, o estatuto dos professores surdos e o estatuto da língua de sinais ainda trazem as marcas de representaçôes educativas empunhadas, implícita mas permanentemente, por uma referência à imagem da criança ouvinte em relaçáo à língua francesa, assim como ao arquétipo do adulto encarregado de ensinar primeiramente uma modalidade audiofonatória. A presença, na educaçáo dos surdos, de participantes majoritariamente ouvintes, vendo-se eles mesmos deficientes em sua missão ou considerando ainda a LSF como uma "língua-prótese em uma prescrição de último recurso no tratamento da deficiência" (MILLET, 1999, p. 111), contribui para a inércia diante de uma possível mudança de paradigma.

\footnotetext{
${ }_{52}$ Mottez e Markowicz tinham começado uma pesquisa que originou, em 1979, o relatório "Integraçáo ou Direito à diferença, as consequências de uma escolha política sobre as estruturaçôes e o modo de existência de um grupo minoritário, os surdos", publicado em versão bilíngue (inglês e francês) em um número especial da revista Langages, em dezembro de 1979, dirigida por Grosjean e Lane.
} 
Já em 1993, Mottez resumia o que aqui quisemos abordar:

\begin{abstract}
Se essa pedagogia muda pode ser qualificada de tipicamente surda, o que dizer? Qualificar de tipicamente surdas certas aptidôes não significa necessariamente que inexistam radicalmente nos ouvintes. Acontece somente que, funcionando em outras modalidades e outros contextos, os ouvintes não as desenvolveram suficientemente. Qualificar de tipicamente surdos certos modos de fazer não significa que os ouvintes não possam, quando for a ocasiấo, proceder espontaneamente da mesma maneira ou que eles não possam a fortiori nelas se inspirar ou delas se apropriar. Eles podem aprendêlas. Quando hoje se fala de pedagogia a respeito dos participantes surdos, só se pensa, é verdade, naquela que deveriam lhes ensinar os especialistas ouvintes - para que eles se tornem bons professores. É por isso que insisto naquela pedagogia que eles talvez também pudessem ensinar aos ouvintes (MOTTEZ, in BENVENUTTO, 2006, p. 175).
\end{abstract}

Obrigando-nos a deslocar a perspectiva, uma tal análise implica renovar o pensamento coletivo, melhorar os programas de formaçáo, conceber e variar os suportes pedagógicos, produzindo ainda muitos outros efeitos que não podemos prever. Nem por isso a colaboração em torno das questôes ligadas à surdez deve funcionar de forma isolada. Uma abertura para as questóes de fundo fora do campo da surdez é desejável. Com efeito, passando pelo prisma oferecido pelo estudo das LS e de seus locutores, a complexidade das línguas e das situaçôes linguageiras tira partido de uma nova decomposição das noçôes mobilizadas. Isso permite que os surdos sejam reconhecidos no mundo da pesquisa por temas que lhes dizem respeito, ou não, e que se abram para questôes gerais. Desse modo, a distinçáo entre surdos e ouvintes não mais terá razão de ser.

Nem todas as questốes levantadas encontrarão seu lugar no interior de uma didática das línguas e das culturas e, por isso, é desejável que as associemos em uma didática específica das línguas de sinal ${ }^{53}$. Nesse sentido, é necessário ter uma perspectiva internacional e transdisciplinar, inspirandose, por exemplo, nos deafstudies de outros países e articulando-a em torno de vários eixos de estudos (aquisicional, cognitivo, linguístico, pedagógico...), a fim de objetivar em conjunto o que o uso de uma língua gestual oferece à didática das diversas disciplinas escolares. Tendo em conta que um forte vínculo existe entre as diversas línguas surdas de cada país, reunir um

\footnotetext{
${ }^{53}$ Lembremos que o modelo de Cuxac (2000) estabelece, por um lado, um elo entre as línguas de sinal emergentes e as línguas de sinal institucionais (elo filogenético) e, por outro, um elo entre as estruturas gramaticais específicas e as unidades lexicais (elo diacrônico). A etimologia dessas unidades é decorrente de um processo de iconicização da experiência.
} 
conjunto de didáticas das línguas sinalizadas permitiria uma reflexão mais realçada em torno da surdez e de outras formas de ensinar. A construçáo de uma didática da LS (e não unicamente da LSF) aberta a questóes conexas e a criação de deaf studies à francesa podem se fortalecer reciprocamente para remexer as questóes socioantropológicas, psicológicas, históricas etc., em torno da LSF e de seus locutores.

Para concluir, a nosso ver, interessar-se pela minoria surda revelase particularmente produtivo na análise das questóes ligadas de perto ou de longe à construção de uma sociedade inclusiva. Que este artigo possa contribuir, por pouco que seja, para o processo já iniciado por outros, pesquisadores e atores de campo.

\section{Referências}

Obras e artigos

BENVENUTO, A. Le Sourd émancipé? Paris: L'Harmattan, 2006.

BIAP (Bureau International d'Audiophonologie). Le bilinguisme dans l'éducation et l'enseignement de l'enfant sourd. Recommandation 17/3 [en ligne], Corfou, 2003. Disponível em: http://www.biap.org/fr/ archives/72-ct-17-communication-/47-recommandation-biap-173-lebilinguisme-dans-leducation-et-lenseignement-de-lenfant-sourd. Acesso em: 30 jul. 2018.

BURGAT, S. Un exemple atypique d'acquisition du langage écrit en contexte bilingue: l'enfant sourd locuteur de la langue des signes qui apprend à lire et à écrire en français. Colloque Jeunes Chercheurs en Acquisition du Langage, Université de Lyon, les 3 et 4 décembre 2009.

BUTON, F. L'administration des faveurs. L'État, les sourds et les aveugles (1789-1885), Presses universitaires de Rennes, 2009, p. 311 (Histoire).

COSTE, D. Linguistique de l'acquisition et didactique des langues : repères pour des trajectoires. In Bouchard, R., Billiez, J., Colletta, J.-M., De Nuchèze, V. \& A. Millet (dir.) Acquisition et enseignement apprentissage des langues. Grenoble: Université Stendhal, 1992, p. 319-328.

COURTIN, C. La nouvelle revue de l'AIS. Actes du colloque «Concep- 
tualisation et surdité» de mai 2001, 17, 1er trim, Suresnes, 2002, p. 181195.

COURTIN, C., LIMOUSIN, F.; A. MORGENSTERN. Évaluer les compétences linguistiques des enfants en langue des signes, une expérience pionnière [en ligne], Language, Interaction and Acquisition, John Benjamin Publishing Company, p. 129-158, 2010. Disponível em: https://halshs.archives-ouvertes.fr/halshs-00531659. Acesso em: 30 jul. 2018.

CUXAC, C.; E. ANTINORO PIZZUTO. Émergence, norme et variation dans les langues des signes: vers une redéfinition notionnelle [en ligne]. Langage et société, n. 131, v. 1, p. 37-53, 2010. Disponível em: doi:10.3917/ 1s.131.0037. Acesso em: 30 jul. 2018.

CUXAC, C. Une manière de reformuler en langue des signes française [en ligne], La linguistique, n. 43, 2007, p. 117-128. Disponível em: doi:10.3917/ling.431.0117. Acesso em: 30 jul. 2018.

CUXAC, C. La langue des signes française: les voies de l'Iconicité, Faits de Langues, n. 15-16, Paris: Ophrys, 2000.

DALLE, P. Histoire et philosophie du projet bilingue. L'ANPES et le rôle des parents [en ligne], Enseigner en LSF, La nouvelle revue de l'AIS, Hors série 2005. 2005. Disponível em: http://anpes.free.fr/Doc/NRAIS HS05-Dalle. pdf. Acesso em: 30 jul. 2018.

DALLE-NAZEBI, S. Chercheurs, Sourds et Langue des Signes. Le travail d'un objet et de repères linguistiques, Thèse (doctorat en sociologie), Université Toulouse 2 - Le Mirail, 2006.

EBERSOLD, S. INS-HEA, séminaire du 27 mars 2013, sur «L'orchestration de l'accessibilité à l'enseignement supérieur», 2013.

FELDMAN, N. La position des professionnels entendants dans l'association 2LPE, Mémoire (Maîtrise de Sociologie mention Anthropologie), Université Paris 8 Vincennes-Saint-Denis, Paris, 2001, 143 p.

FUSELLIER-SOUZA, I. La création gestuelle des individus sourds isolés. De l'édification conceptuelle et linguistique à la sémiogénèse des langues des signes, AILE (Acquisition et Interaction en Langue Étrangère), n. 15, Paris, p. 61-96, 2001.

GARCIA, B.; M. DERYCKE. Introduction [en ligne], Langage et société, n. 131, v. 1, p. 5-17, 2010. Disponível em: doi:10.3917/ls.131.0005. Acesso em: 30 jul. 2018.

GARCIA, B.; S. BURGAT. Évolution institutionnelle et sociale de la 
Langue des Signes Française (LSF) et de ses locuteurs sourds: place et rôle de l'Université. In: Hélot, C.; J. Erfurt (eds). L'éducation bilingue en France: politiques linguistiques, modèles et pratiques, Lambert-Lucas, 2016, p. 332-346.

GEFFROY, V. La formation des pédagogues sourds. Étude exploratoire. Thèse (doctorat en didactique des langues et des cultures), Université de Paris 8/Vincennes-Saint-Denis, 2015.

GROSJEAN, F. ; H. Lane. Psycholinguistique et langue des signes, Langage, n. 56, p. 35-57, 1979.

GROSJEAN, F. Le droit de l'enfant sourd à grandir bilingue [en ligne], Revue Internationale Surdités, décembre 2000, n. 3, p. 90-93. Disponível em: http://www.francoisgrosjean.ch/the right fr.html. Acesso em: 30 jul. 2018.

HAMM, M. L'apprentissage de la lecture et de l'écriture chez les personnes sourdes et malentendantes. Thèse (doctorat en Sciences de l'Éducation), Université de Strasbourg, 2010.

HÉLOT, C. ; J. ERFURT. L'éducation bilingue en France. Politiques, linguistiques, modèles et pratiques, Lambert-Lucas, 2016.

HUGOUNENQ, H. L'enseignement de la Langue des Signes aux entendants. Son histoire, ses enjeux au niveau des représentations collectives, ses conséquences concrètes sur la vie des Sourds, Mémoire de DEA en Anthropologie sociale et Ethnologie, EHESS, Paris, 2003, 141 p.

KAHNE, B-P. Deaf Tips: Douze leçons du monde des Sourds pour améliorer sa communication personnelle, sociale et professionnelle, 2013.

KERBOURC'H, S. Le Réveil Sourd. D'hier à Aujourd'hui (1971-2006): de l'action collective d'un mouvement socioculturel pour la réhabilitation de la Langue-des-Signes-Française à la construction d'une identité collective pour la participation sociale des sourds, Thèse (doctorat en Sociologie), EHESS, Paris, 2006.

LEROY, É. Didactique de la langue des signes, langue 1, dans les structures d'éducation en langue des signes. Attitudes et stratégies pédagogiques de l'enseignant sourd. Thèse (doctorat en Sciences du langage), Université Paris 8 - Vincennes-Saint-Denis, Paris, 2010.

MATO, O. Le nouveau paradigme de la surdité et les dynamiques professionnelles: Analyse de la place et du rôle des professionnels entendants de la surdité à partir des années 1970. Thèse (doctorat en Sociologie), Université Paris 8, Paris, 2017. 
MATSUOKa, E. Études supérieures: visibilité et réalité d'une politique du handicap. Le cas de la surdité, NRAS: Handicap, parole de témoin et parole d'expert : vers une co-construction des discours?, n. 75, Suresnes, 2016.

MEIRIEU, P. Faut-il en finir avec la pédagogie? Conférence donnée à Toulouse dans le cadre du GREP le 22 novembre 2009 [en ligne], Toulouse: GREP, 2009. Disponível em: https://www.meirieu.com/ARTICLES/ GREP CONF pedagogie.pdf. Acesso em: 30 jul. 2018.

MEYNARD, A. Journal de l'AFILS, n. 85, set. 2013, p. 34.

MILLET, A. Orthographe et écriture, langage et surdité: systèmes, représentations, variations. Habilitation à Diriger des Recherches, Université Stendhal, Grenoble 3, 1999.

MINGUY, A. Le Réveil Sourd en France. Pour une perspective bilingue. Paris: L'Harmattan, 2009.

MOTTEZ, B. Les sourds existent-ils? Textes réunis et présentés par A. Benvenuto, Paris: L'Harmattan, 2006.

MOTTEZ, B. La surdité dans la vie de tous les jours [en ligne], Cahiers du CTNERHI, Publications CTNERHI, 114 p, 1981. Disponível em: http://classiques.uqac.ca/contemporains/handicap et inadaptation/documents CTNERHI/CTNERHI 095/CTNERHI 095.pdf. Acesso em: 30 jul. 2018.

PERINI, M. Analyse des particularités observées dans des productions écrites d'adultes sourds, Les Actes de Lecture, n. 114, jun. 2011, Paris: Association Française pour la Lecture (AFL).

TERRAIL, J.-P. De l'oralité : essai sur l'égalité des intelligences, Paris: La Dispute, 2009.

\section{Textos regulamentares}

Bulletins officiels du Ministère de l'Éducation Nationale:

No33 du 4 septembre 2008.

$\mathrm{N}^{\circ} 25$ du 24 juin 2010.

\section{Circulares}

Circulaire $n^{\circ} 2010-068$ du 28-5-2010. Bulletin officiel $n^{\circ} 25$ du 24 juin 
2010.

NOR : MENE1013746C, MEN - DGESCO - B2-2.

Circulaire $n^{\circ}$ 2017-011 du 3 février 2017, pour la Mise en oeuvre du parcours de formation du jeune sourd. Bulletin officiel n 8 du 23 février 2017. NOR: MENE1701591C, MENESR - DGESCO A1-3. 